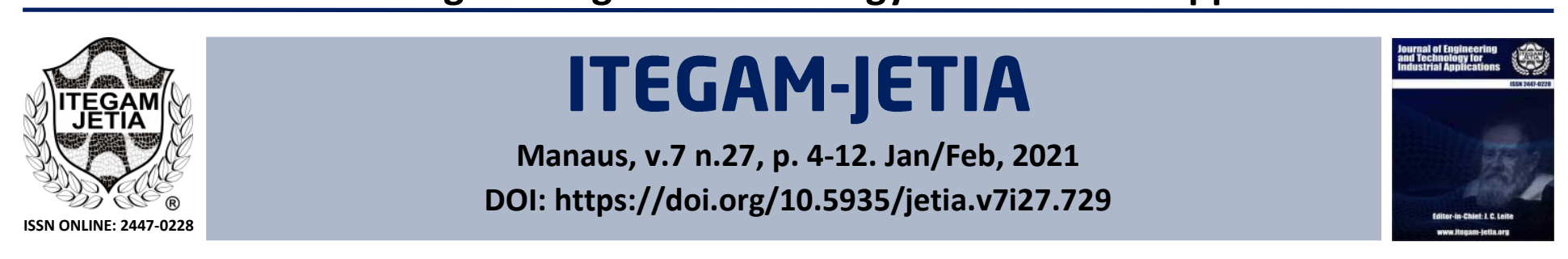

\title{
COMPARISON OF MAXIMUM POWER POINT TRACKING TECHNIQUES USED IN PHOTOVOLTAIC SYSTEM
}

\author{
Miguel Aybar Mejias', Yandi Gallego Landera ${ }^{2}$ and Lesyani León Viltre*3 \\ ${ }^{1}$ Santo Domingo Technological Institute - INTEC. Santo Domingo, Dominican Republic. \\ ${ }^{2}$ Federal University of Pernambuco - UFPE. Recife, Brazil. \\ ${ }^{3}$ Marta Abreu de las Villas Central University - UCLV. Villa Clara, Cuba. \\ ${ }^{1}$ http://orcid.org/0000-0002-4715-3499 (i), ${ }^{2}$ http://orcid.org/0000-0002-9576-4796 (i), ${ }^{3}$ http://orcid.org/0000-0003-1822-2480 (1)
}

Email: miguel.aybar@intec.edu.do, yandigallego@gmail.com, *lesyani@uclv.edu.cu

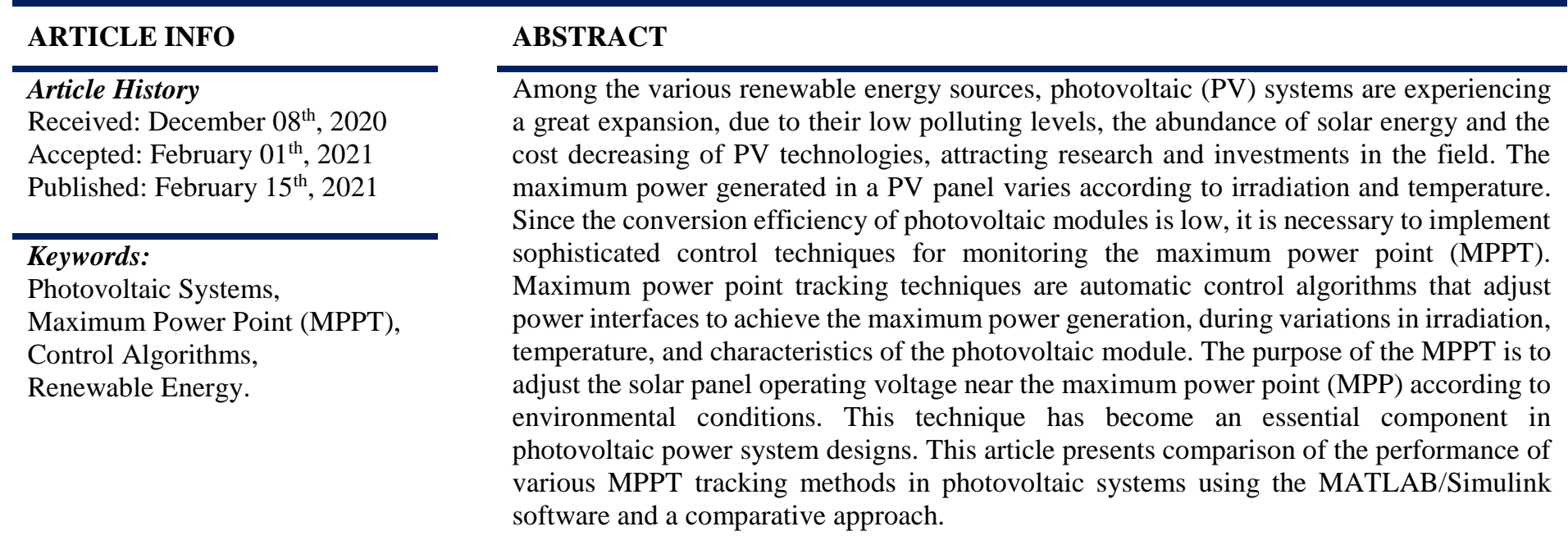

Copyright (02016 by authors and Galileo Institute of Technology and Education of the Amazon (ITEGAM). This work is licensed under the Creative Commons Attribution International License (CC BY 4.0).

\section{INTRODUCTION}

The use of photovoltaic (PV) systems has been growing in the last decade. However, this type of generation has two critical disadvantages: the high cost of installed capacity and efficiency ranges between $9 \%-15 \%$ [1], which is considered low. Considering the above, it requires the use of maximum power point tracking techniques (MPPT) to generate maximum power according to the variable environmental conditions [2]. In this way, methods such as Perturb \& Observe and incremental conductance have been widely used because they are easy to implement and converge quickly the MPP [3-6]. However, in some situations, the photovoltaic system may be subject to variations in irradiation and temperature, and a point different from the point of maximum power may follow its output characteristic curve [6-8]. That is why this article does not just seek to present several of the most used methods in the literature, but to compare them computationally, using reliable and internationally consolidated software. Six MPPT methods applied to a buck-type system connected to a photovoltaic generator will be presented and simulated in MATLAB/Simulink. Finally, a comparison will be made between the simulated methods.

\section{THEORETICAL REFERENCE}

The MPPT methods consists of a DC/DC converter comprising a stage that liaison algorithm that receives information from the photovoltaic system, and a second power stage responsible for requesting the voltage and current that correspond to the desired values according to the environmental conditions of temperature and irradiation.

The objective is to analyze its response to variations in temperature and irradiance. Of the selected methods two are of constant relationship: constant cyclic ratio (Rcte) and constant voltage (Vcte), the rest of the chosen methods: Perturbe \& Observe classic (P\&OC), Perturb \& Observe modified (P\&OM), Conductance Incremental (CI) and Modified Incremental Capacitance (CIM). Each of these methods is described below. 


\section{II.1 CONSTANT CYCLICAL RATIO METHOD (Rcte)}

This is the simplest of the methods analyzed because there is no feedback or control. The cyclical ratio is adjusted only once and remains constant.

\section{II.2 CONSTANT VOLTAGE METHOD (Vcte)}

This technique is based on the premise that the maximum power voltage has an approximate linear relationship independent of the external factors. The voltage factor depends on the characteristics of the PV array used and is empirically calculated. The value falls between 0.7 and 0.8 .

The method uses only one sensor. Figure 1 shows the algorithm presented in [9].

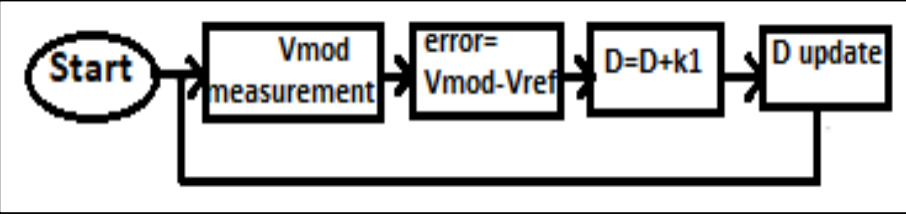

Figure 1: Algorithm for the constant-voltage method. Source: Authors, (2020).

\section{II.3 PERTURB \& OBSERVE CLASSIC(P\&OC))}

This technique is the most widely used due to its simple implementation. As the name suggests, the method involves disturbing the voltage of the photovoltaic array in one direction and observing the output power. If the power increase, the disturbance continues in the same direction, otherwise the disturbance changes the direction as shown in Figure 2.

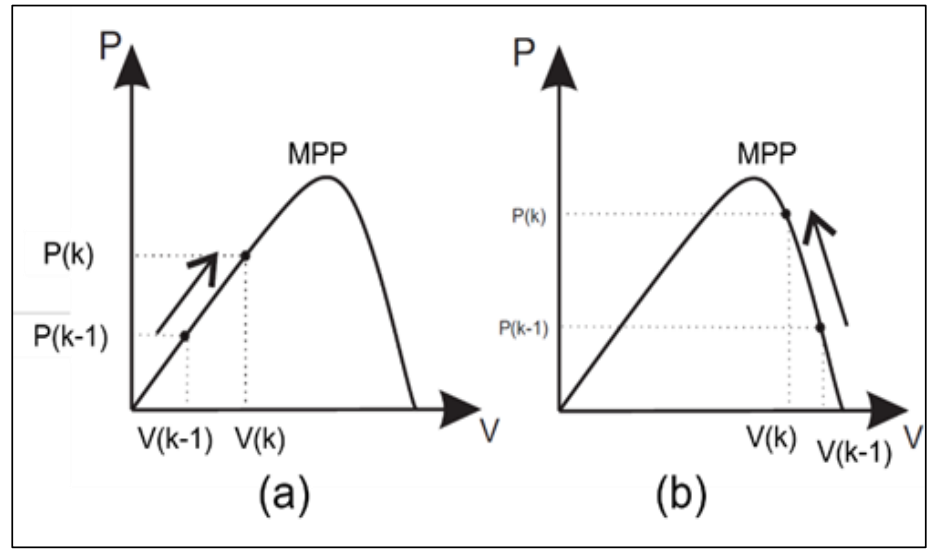

Figure 2: P\&OC algorithm. (a) power increase, (b) Decrease power disturbance changes direction.

Source: Authors, (2020).

As the process is continuously repeated, the maximum power point is never reached because the disturbance is always carried out, leaving the system oscillating next to it in a permanent regime. Figure 3 shows the flowchart of the method.

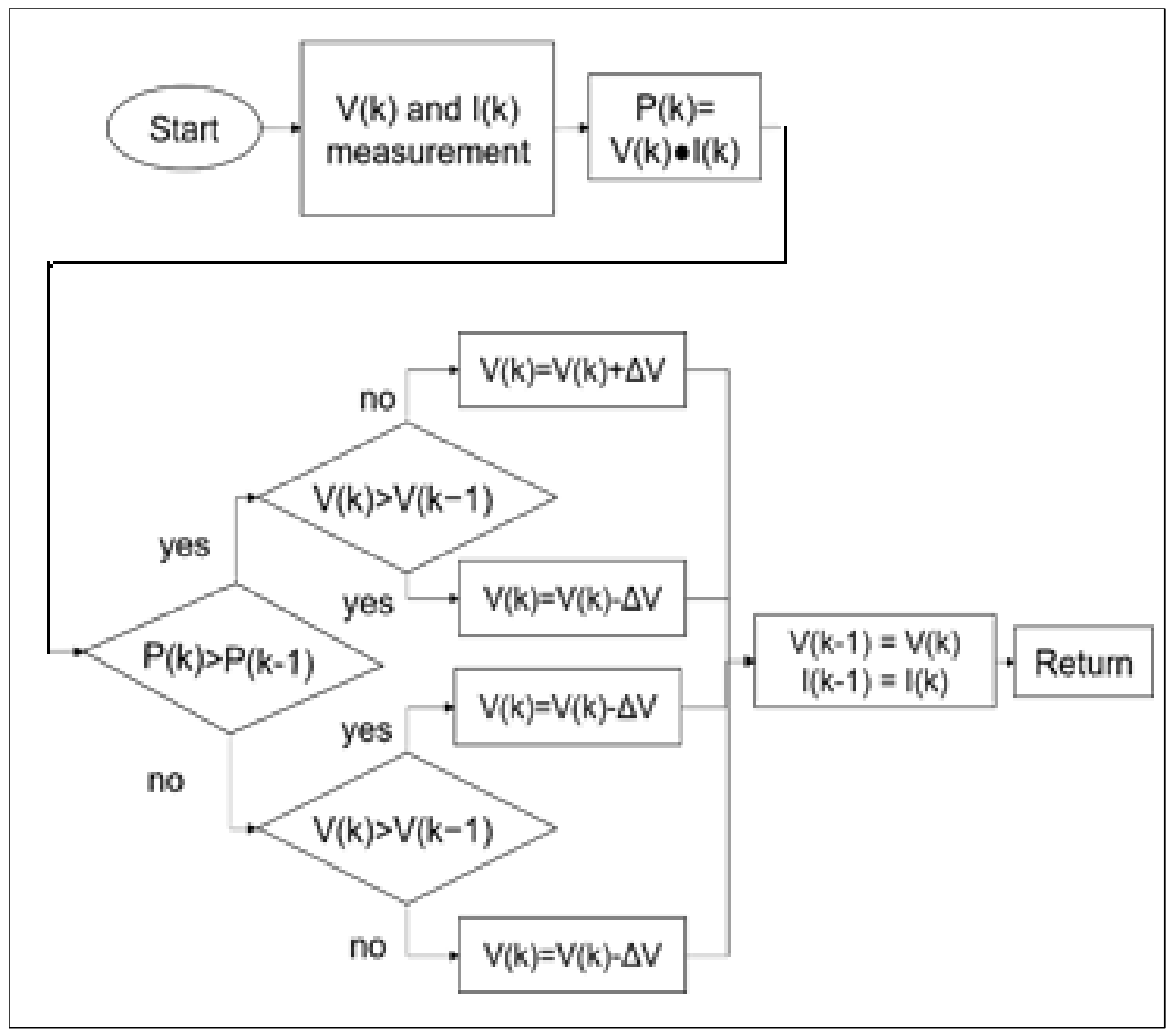

Figure 3: P\&OC method flowchart.

Source: Authors, (2020).

\section{II.4 PERTURB \& OBSERVE WITH STOP CRITERION (P\&OM) CLASSIC (P\&OC)}

This method is similar to the previous one with a small modification, consisting in the implementation of a stopping criterion in the algorithm; this is done to reduce the oscillations in a permanent regime. The flow chart of this method is shown in Figure 4. 


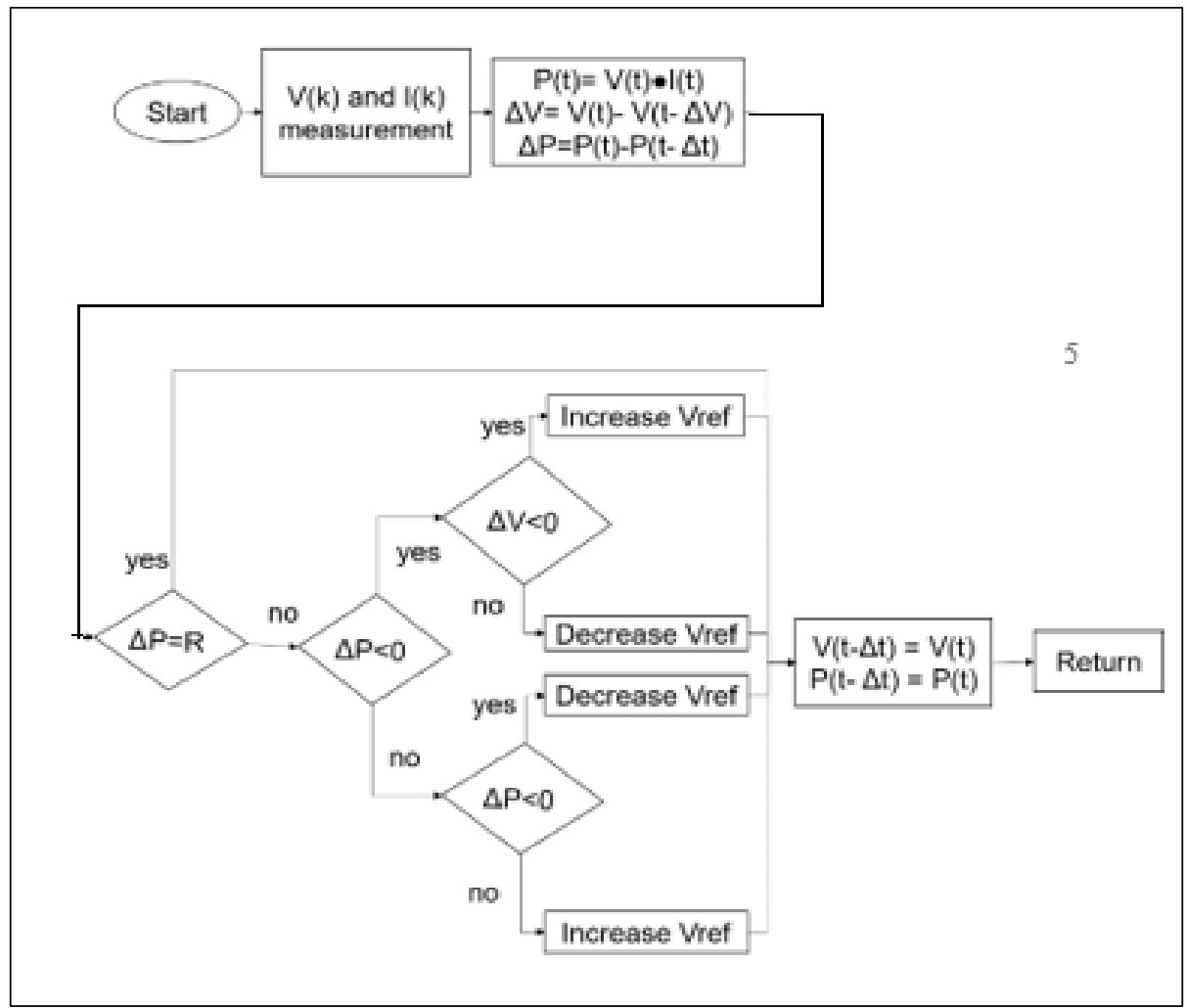

Figure 4: P\&OM method flowchart.

Source: Authors, (2020).

\section{II.5 INCREMENTAL CONDUCTANCE (IC)}

The method is based on the instantaneous and incremental conductance values of the photovoltaic array. Current and voltage measurements are necessary, and through these, the power obtained by the voltage can be derived. Equation 1 can describe the method

$$
\frac{d P}{d V}=\frac{\mathrm{d}(V I)}{\mathrm{dV}}=I \frac{d V}{d V}+V \frac{d I}{d V}=I+V \frac{d I}{d V} \cong I+V \frac{\Delta I}{\Delta V}
$$

Basically, there are three situations for incremental conductance on PV module: $\boldsymbol{I}+\boldsymbol{V} \frac{\Delta \boldsymbol{I}}{\Delta \boldsymbol{V}}>\mathbf{0}$, Figure 5 (a), the action is to increase the output voltage. $I+V \frac{\Delta I}{\Delta V}=\mathbf{0}$, Figure $5(\mathrm{~b})$, the action is to maintain the output voltage. $I+\boldsymbol{V} \frac{\Delta \boldsymbol{I}}{\Delta \boldsymbol{V}}<\mathbf{0}$, Figure 5 (c), the action is to decrease the output voltage.
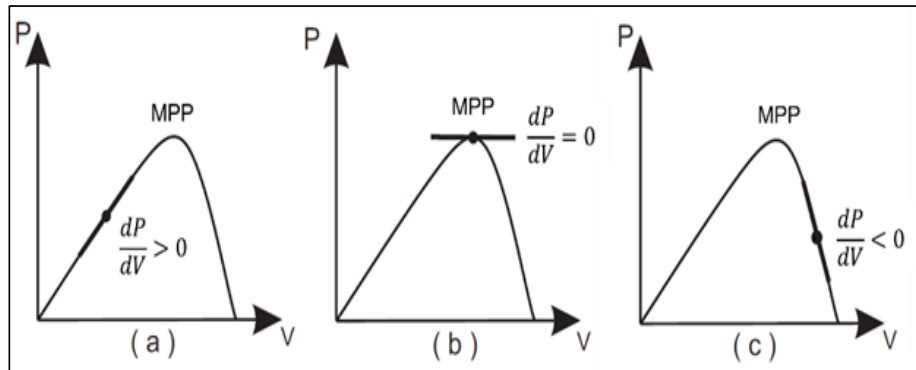

Figure 5: CI algorithm.

Source: Authors, (2020).

If $\Delta \mathrm{V}$ is equal to zero, which can occur when there is variation in irradiation and not in temperature, $\Delta \mathrm{I}$ must be analyzed to determine the type of action to be taken. Figure 6 presents the flow chart of the Incremental Conductance method.

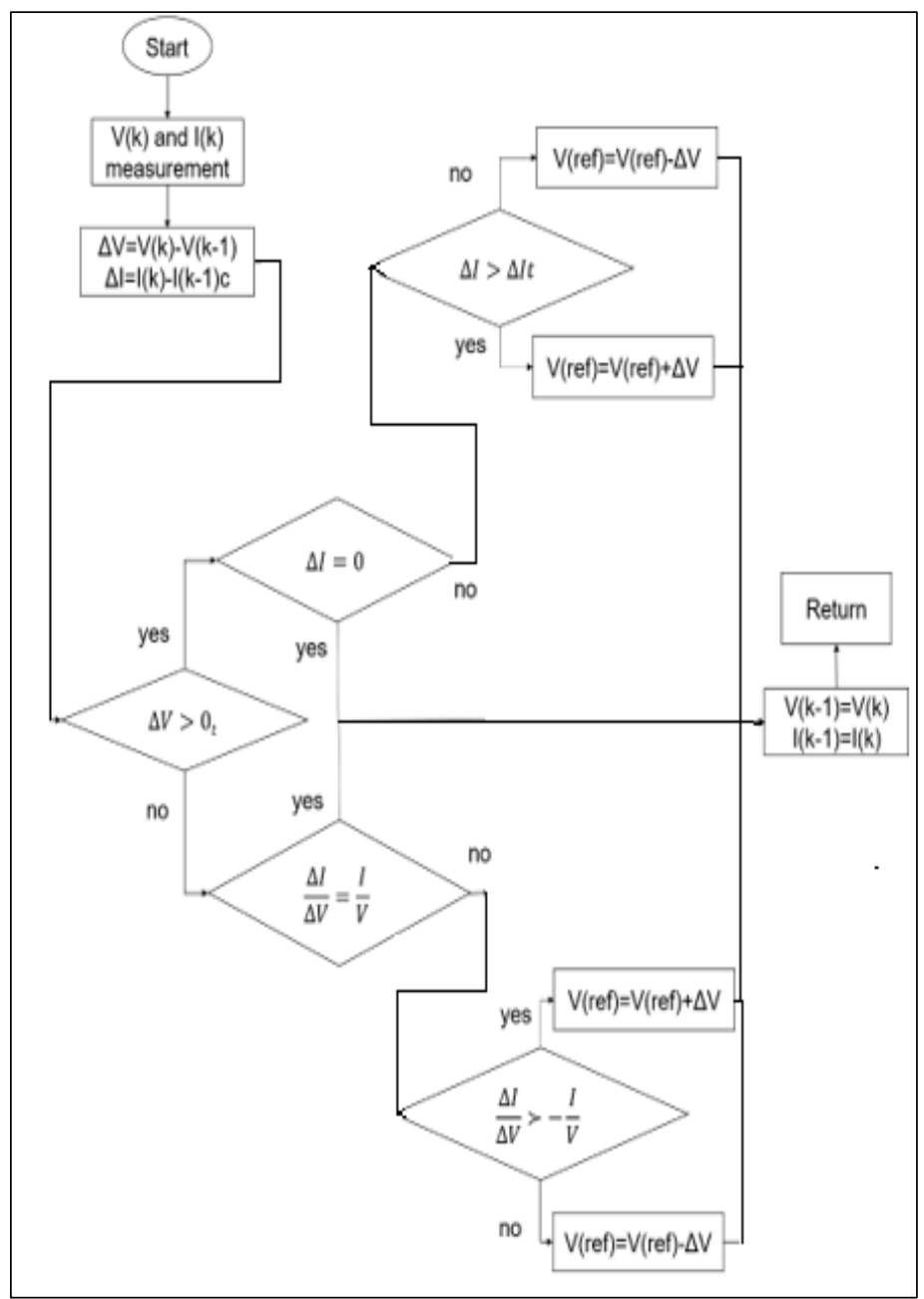

Figure 6: CI method flowchart. Source: Authors, (2020). 


\section{II.6 MODIFIED INCREMENTAL CONDUCTANCE (CIM)}

This method takes into account the term that indicates that the system is in MPPT, that describes Equation 2:

$$
\frac{I}{V}+\frac{d I}{d V}=0
$$

In practice, this criterion will hardly be satisfied due to measurement errors, quantization errors, and discretization of the reference voltage. It is, therefore, necessary to define a tolerance range $(\Delta \boldsymbol{\omega})$ in which the situation can be considered correct. The flow chart in Figure7 presents the operation of this method [10].

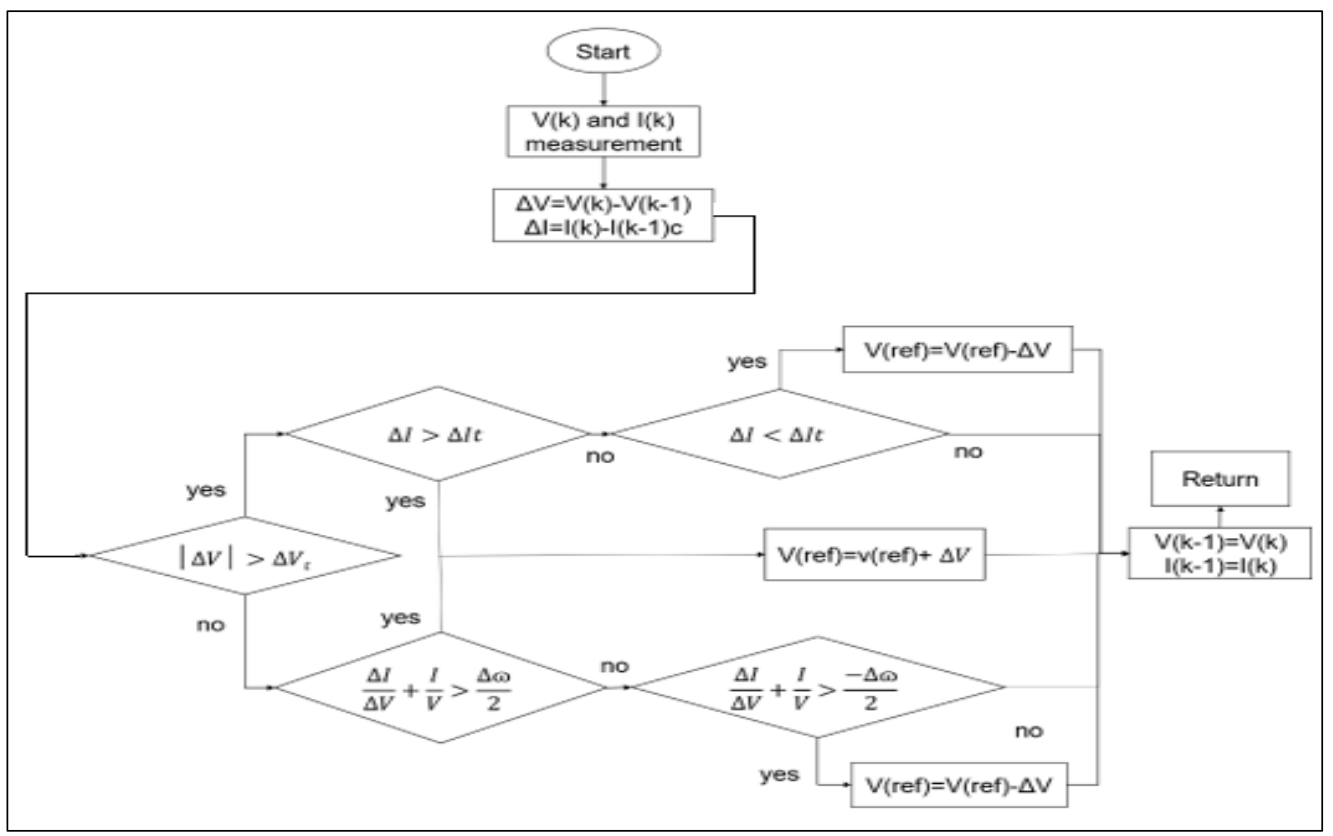

Figure 7: CIM method flowchart.

Source: Authors, (2020).

\section{MATERIALS AND METHODS}

The simulation model used is a two-state inverter, as shown in the following Figure 8 (a). Where the objectives of the DC/AC inverter are: Synthesize the current to be injected into the electrical network and adjust the voltage of the $\mathrm{DC}$ bus ( $\mathrm{C}_{\mathrm{DC}}$ capacitor), while the DC/DC converter (Boost) has the objective of controlling the voltage in the $\mathrm{PV}$ terminals (Capacitor $\mathrm{C}_{\mathrm{PV}}$ ). Considering the network as an infinite bus and the DC/AC inverter controlling capacitor voltage correctly, we can then represent the system as shown in Figure 8 (b).

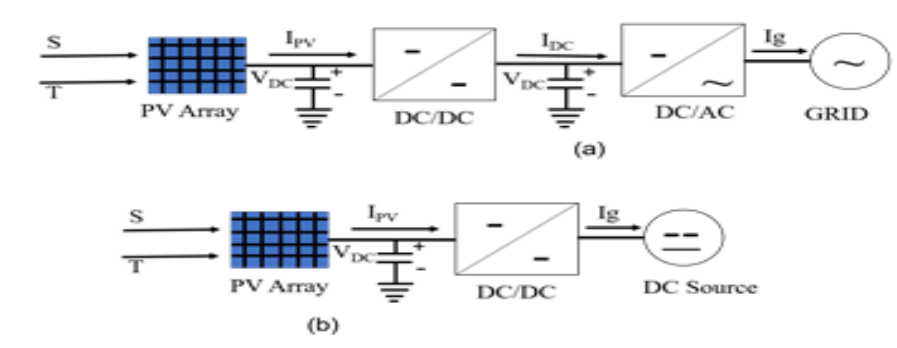

Figure 8: Diagram used for the simulation (a) and Simulated reduced diagram $(b)$.

Source: Authors, (2020).

Considering the network as an infinite bus and the DC/AC inverter controlling capacitor voltage correctly, we can then represent the system as shown in Figure 9.

\section{III.1 PHOTOVOLTAIC MODULE}

To research with photovoltaic modules, it is necessary to know first the operation and characteristics of the modules. Various techniques for estimating parameters for photovoltaic modules were found in the literature. This article will use the technique presented by Xiao in [11]. This technique is based on the fact that the derivative of the power about the voltage in a photovoltaic module is zero at the maximum power point. Also, the influence of $\mathrm{Rp}$ (parallel resistance of the photovoltaic module circuit) is neglected. The flowchart used to determine the new parameters of the photovoltaic module in the condition of variations in temperature and irradiance is shown in Figure 9.

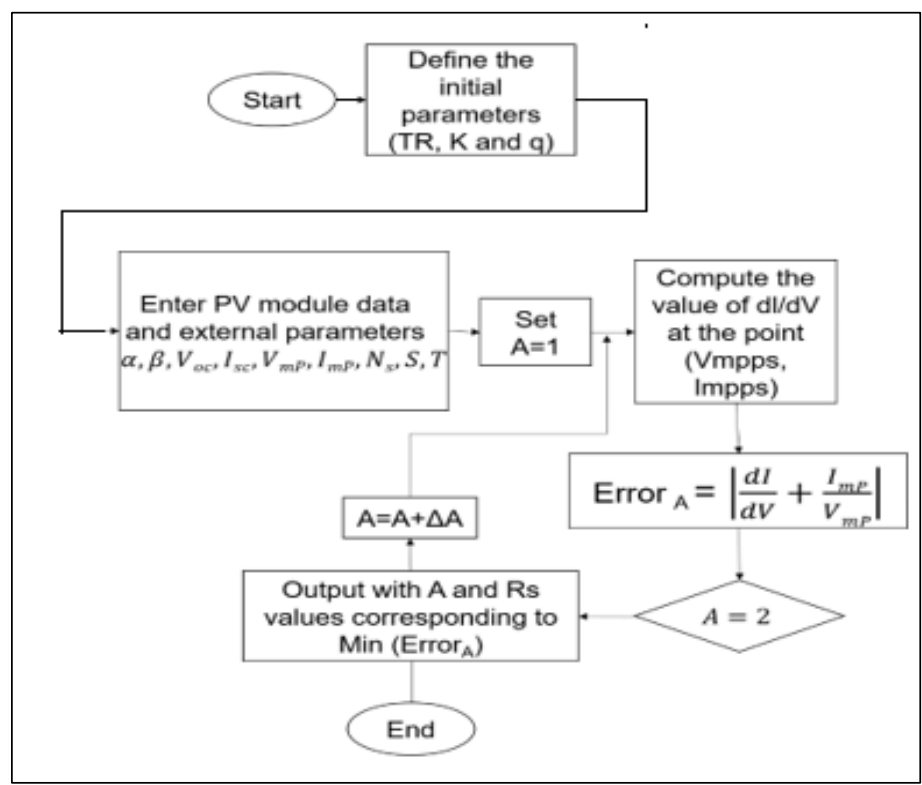

Figure 9: Flowchart of the technique used by Xiao for parameter estimation.

Source: Authors, (2020). 


\section{The variables are:}

$\alpha$ : Coefficient that relates the variation in the short circuit to that in the temperature, $\beta$ : Temperature coefficient of $\mathrm{V}_{\mathrm{OC}}, \mathrm{V}_{\mathrm{OC}}$ : Open circuit tension, $\mathrm{V}_{\mathrm{SC}}$ : Short-circuit current, $\mathrm{V}_{\mathrm{mpp}}$ : Voltage at the maximum power point, $\mathrm{N}_{\mathrm{S}}$ : Number of cell-associated in series in the PV module, $\mathrm{S}$ : Irradiance in $\mathrm{W} / \mathrm{m}^{2}$, T: Temperature $(\mathrm{K})$, Voltage converter.

The Boost converter used in the simulation shows the values that inductance and capacitors can take. Equations 3 to 6, are used to calculate the inductor and capacitor values of the Boost converter input [12].

$$
\begin{gathered}
L_{\text {boost }}=\frac{V_{\text {in }} D}{f_{s} \Delta I} \\
C_{\text {in }}=\frac{\frac{P_{\text {in }}}{V_{\text {in }}}}{f_{s} V_{\text {in }} R_{\text {ip }} V} \\
D=\left(1-\frac{V_{\text {in }}}{V_{\text {out }}}\right) \\
\Delta I=R_{\text {ip }_{\text {Iadmitted }} \frac{P_{\text {in }}}{\text { Pout }}}
\end{gathered}
$$

Where Voltage volts [V], current amps [I], power Watts [P], $R_{i p}$ : admitted ripple (voltage or current), D: cyclical ratio, capacitance Farad [C], $L_{\text {boost }}$ : inductance Henry [H], $f_{s}$ : switching frequency Hertz [Hz]. The subscripts in and out indicate the input and output values, respectively.

The calculated Parameters to consider for the designs of the inductor and capacitor of the boost converter are $\mathrm{L}\left(500 \times 10^{-6} \mathrm{H}\right)$, $\mathrm{C}_{\text {in }}\left(400 \times 10^{-6} \mathrm{~F}\right)$ and $\mathrm{fs}(10 \mathrm{kHz})$. It should be noted that the converter's control is applied to regulate the input voltage to it and not the output voltage as it usually happens. In this case and as explained above, the Boost converter's output capacitor is replaced by a DC voltage source since the voltage is regulated by a second $\mathrm{DC} / \mathrm{AC}$ converter.

\section{RESULTS AND DISCUSSIONS}

Figure 8 shows the PV system simulated in this article. The system consists of a PV array of the type (mSi460A8); it consists of the association of six modules in series. The output of the PV array is connected to a DC/DC Boost converter, which is associated with a three-phase inverter that keeps the output capacitor voltage constant. The data of the photovoltaic module used in the simulation have been taken from the NREL (National Renewable Energy Laboratory) database of standard test condition (STC) parameters are $\mathbf{V}_{\mathbf{O C}} \mathbf{S T C}\left(21.61\right.$ volts), $\boldsymbol{I}_{\boldsymbol{S} \boldsymbol{C}_{\mathbf{S T C}}}$ (5.012 amps), $\boldsymbol{\alpha}$ (0.06644), $\boldsymbol{\beta}(-0.32983)$ and $\mathrm{N}_{\mathrm{s}}(36)$.

The simulation is performed, starting with the photovoltaic module under STC conditions of $\mathrm{S}=1000 \mathrm{~W} / \mathrm{m}^{2}$ and $\mathrm{T}=250^{\circ} \mathrm{C}$. To verify the MPPT algorithm's response and the control of the input voltage to the Boost converter, a variation in the irradiation of $1000 \mathrm{~W} / \mathrm{m}^{2}$ is applied to $500 \mathrm{~W} / \mathrm{m}^{2}$ at $0.3 \mathrm{~s}$ and then after $0.6 \mathrm{~s}$ it is restored to the initial value. At the instant of time $0.9 \mathrm{~s}$, an increase in temperature is applied, varying from 25 to $40^{\circ} \mathrm{C}$.

The figures 10-15 show the responses to these variations in irradiation and temperature of each of the MPPTs analyzed. It is possible to verify that the irradiation and temperature variations result in changes in the modules' voltage to guarantee that the panel's power is maximum. Increasing irradiation increases voltage while increasing temperature results in a reduction in voltage. Also, note that when the variations are applied, the algorithm finds the new point of maximum power transfer.

For the calculation of the cyclical ratio, equation (7) is used, considering six solar modules in series with a voltage of $180 \mathrm{~V}$ in the direct bus and an MPPT voltage of $17.31 \mathrm{~V}$, the cyclical ratio can be calculated.

$$
D=1-\frac{V_{i}}{V_{o}}=1-\frac{6 * 17.31}{180}=0.423
$$

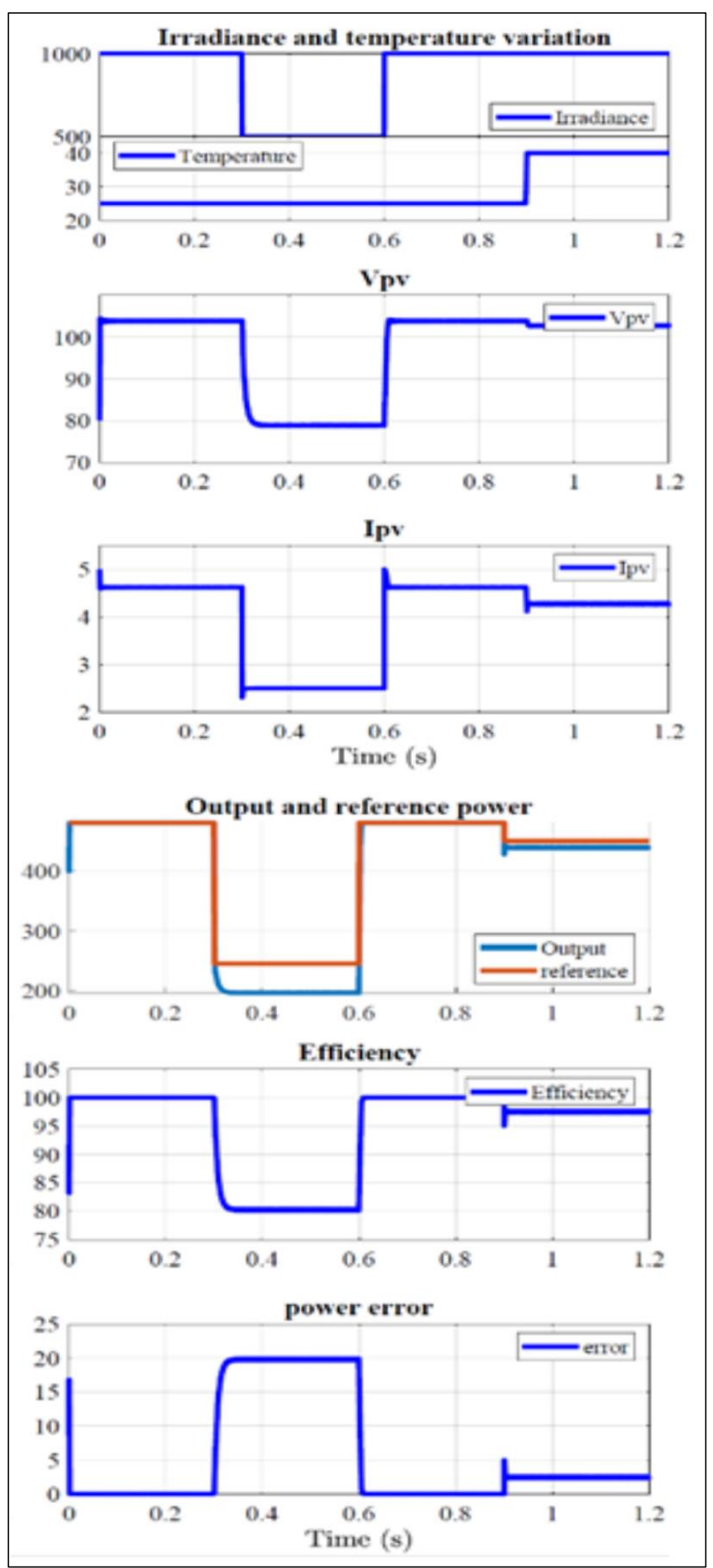

Figure 10: Simulation results of the constant cyclical ratio method.

Source: Authors, (2020). 

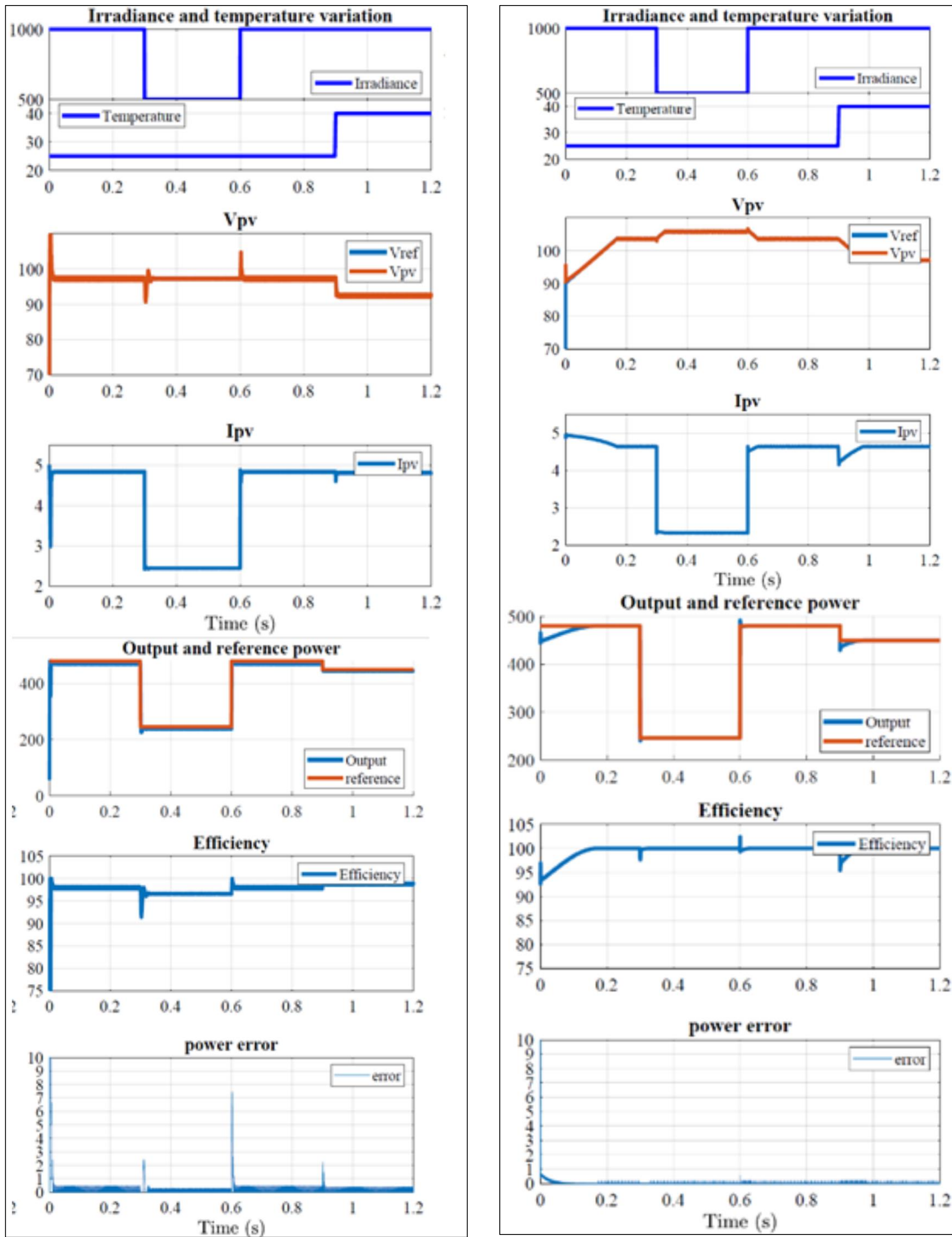

Figure 11: Simulation results of the constant-voltage technique. Source: Authors, (2020).

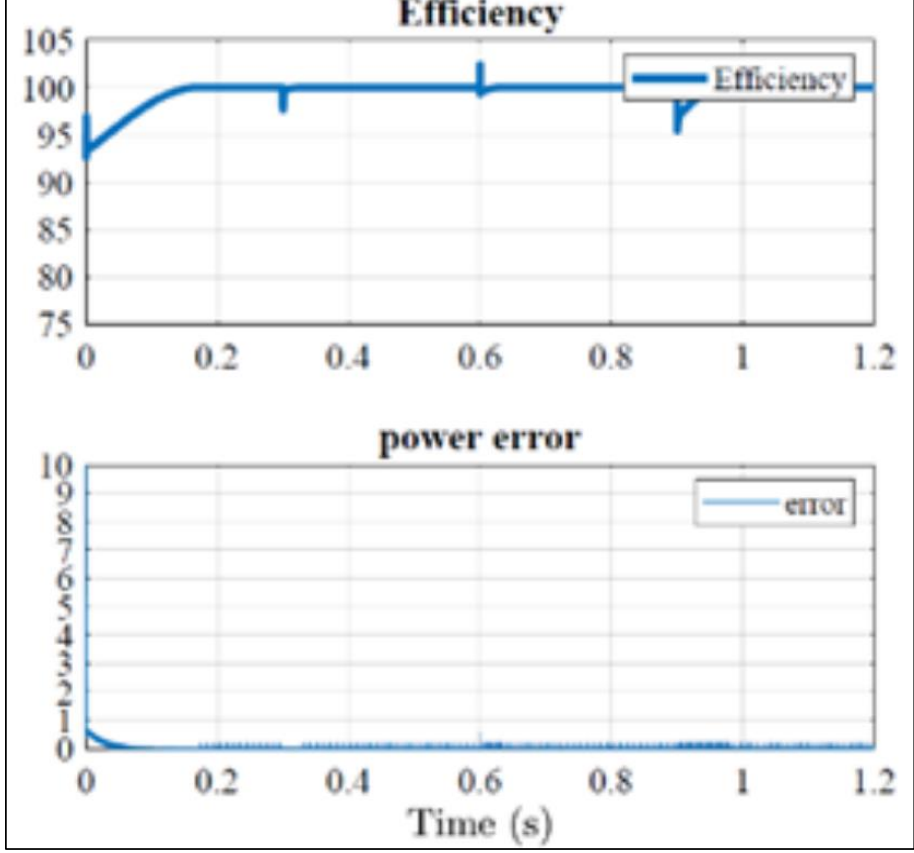

Figure 12: Simulation results of the CI technique. Source: Authors, (2020). 

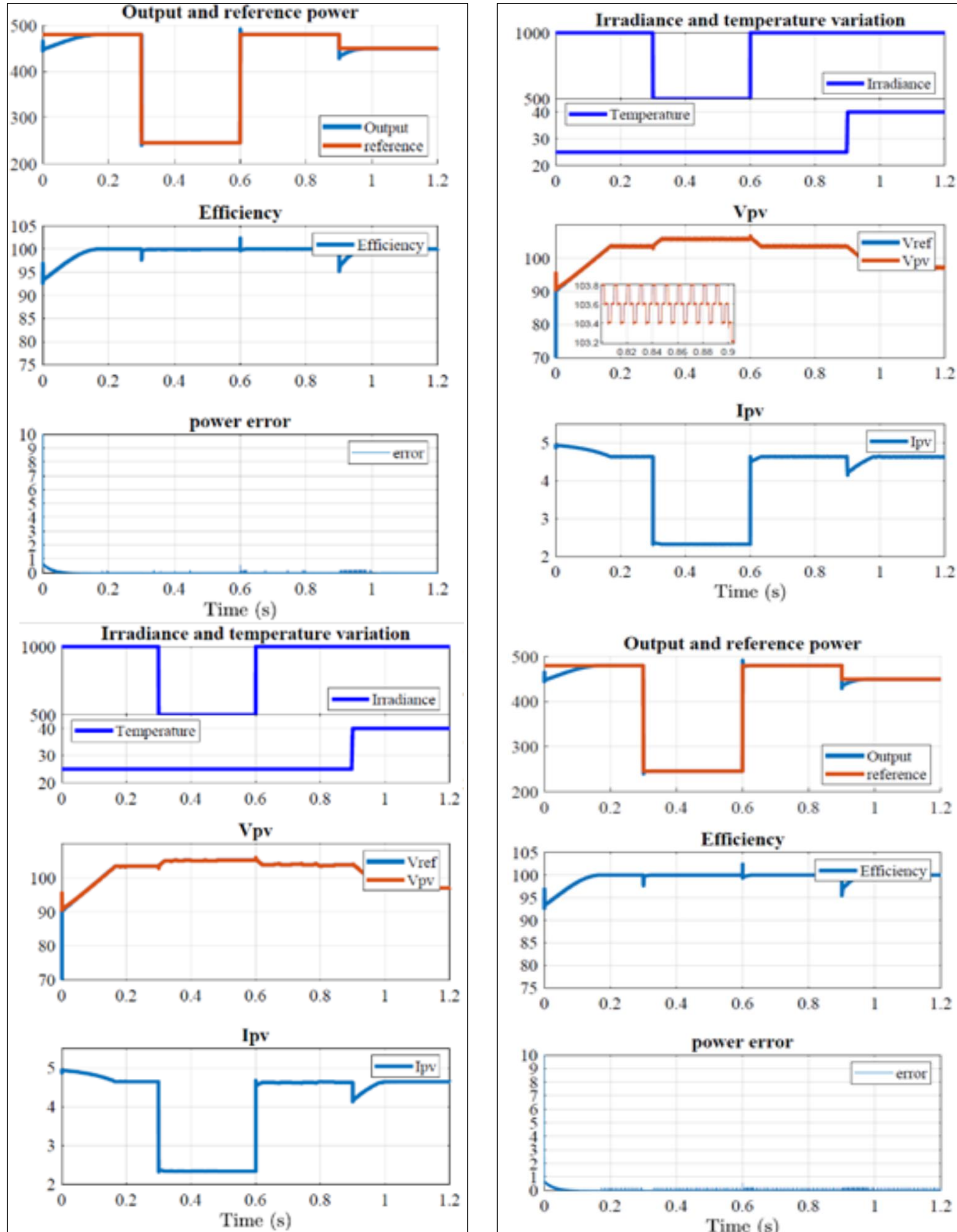

Figure 13: Simulation results of the CIM technique. Source: Authors, (2020).

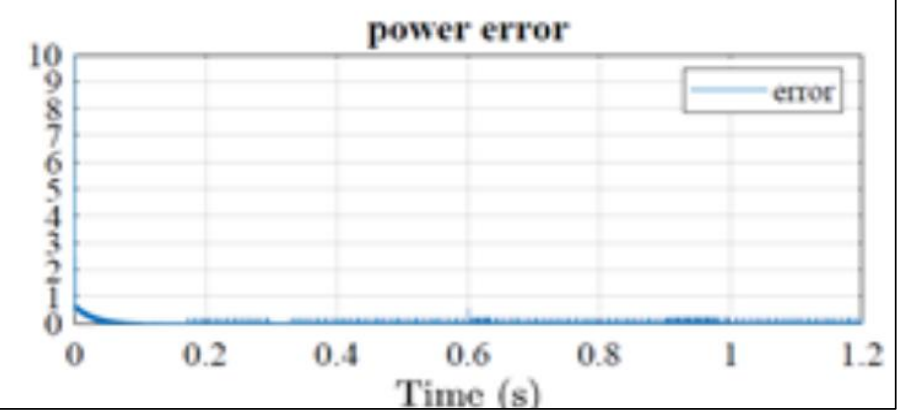

Figure 14: $\mathrm{P} \& \mathrm{OC}$ technique simulation results. Source: Authors, (2020). 


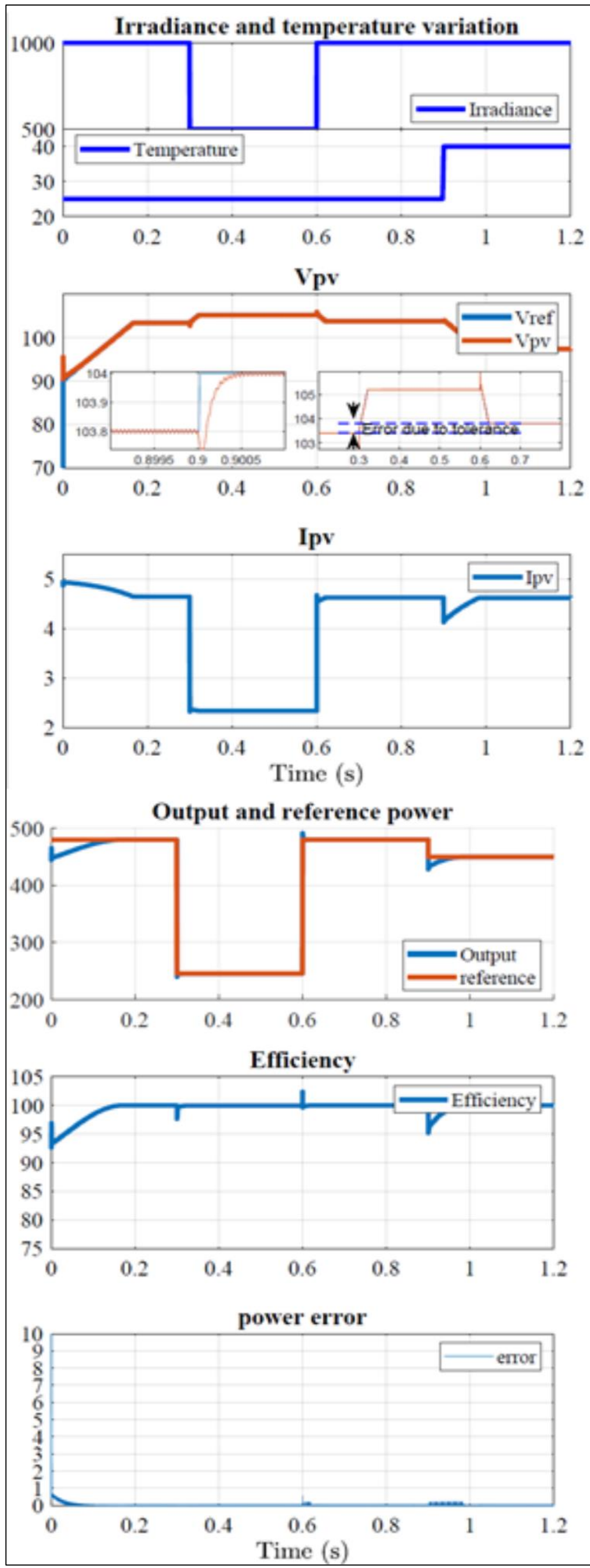

Figure 15: Simulation results of the P\&OM technique. Source: Authors, (2020).
The zoomed-in view in Figure 15 shows the variation in the reference voltage around the MPPT voltage, which is one of the characteristics of this method. This variation is attributed to the lack of algorithm-stopping criterion when the MPP is reached. Finally, Table 1 presents the advantages and disadvantages of each method.

Table 1: Advantages and disadvantages of each MPPT method used.

\begin{tabular}{|c|c|c|}
\hline $\begin{array}{l}\text { MPPT } \\
\text { Method }\end{array}$ & Advantages & Disadvantages \\
\hline $\begin{array}{c}\text { Constant } \\
\text { Cycle Ratio }\end{array}$ & $\begin{array}{l}\text { Low implementation } \\
\text { complexity. }\end{array}$ & $\begin{array}{l}\text { Have a high error in steady-state for } \\
\text { conditions other than tuning. } \\
\text { Cycle reason tuning is done offline. }\end{array}$ \\
\hline $\begin{array}{l}\text { Constant } \\
\text { Voltage }\end{array}$ & $\begin{array}{l}\text { Low implementation } \\
\text { complexity. } \\
\text { If a pilot cell is used, } \\
\text { Vmp tuning is done } \\
\text { online. }\end{array}$ & $\begin{array}{l}\text { If a pilot cell is not used, the } \\
\text { reference voltage is tuned offline. } \\
\text { If a pilot cell is used, it must be } \\
\text { ensured that its operation is in the } \\
\text { same condition as the other PV } \\
\text { modules. } \\
\text { Error in the steady state because } \\
\text { Vmp }=0.75 \text { is always considered. }\end{array}$ \\
\hline $\begin{array}{l}\text { Incremental } \\
\text { Conductance }\end{array}$ & $\begin{array}{l}\text { Online tuning. } \\
\text { Low implementation } \\
\text { complexity. }\end{array}$ & $\begin{array}{l}\text { Has a slow response to rapid } \\
\text { changes in the temperature and } \\
\text { radiation. } \\
\text { Oscillations in the steady state. }\end{array}$ \\
\hline $\begin{array}{c}\text { Modified } \\
\text { Incremental } \\
\text { Conductance }\end{array}$ & $\begin{array}{l}\text { Online tuning. } \\
\text { Low implementation } \\
\text { complexity. } \\
\text { Reduced oscillations. }\end{array}$ & $\begin{array}{l}\text { Has a slow response to rapid } \\
\text { changes in the temperature and } \\
\text { irradiation. } \\
\text { Error in steady-state. }\end{array}$ \\
\hline Classic P\&O & $\begin{array}{l}\text { Online tuning. } \\
\text { Low implementation } \\
\text { complexity. }\end{array}$ & $\begin{array}{l}\text { Slow response to rapid changes in } \\
\text { the temperature and irradiation. } \\
\text { Oscillations in steady-state. }\end{array}$ \\
\hline P\&OM & $\begin{array}{l}\text { Online tuning. } \\
\text { Low implementation } \\
\text { complexity. } \\
\text { Stopping criterion ends } \\
\text { with steady-state } \\
\text { oscillations, but this } \\
\text { implies a small } \\
\text { permanent error. }\end{array}$ & $\begin{array}{l}\text { Has a slow response to rapid } \\
\text { changes in the temperature and } \\
\text { irradiation. }\end{array}$ \\
\hline
\end{tabular}

Source: Authors, (2020).

\section{CONCLUSIONS}

The output power delivered by a photovoltaic field can be maximize using MPPT controls on the system. The use of six MPPT methods applied in MATLAB/Simulink already opens a range of viable options for the control of a photovoltaic system. As seen in the figures, the MPPTs have the desired functionality, keeping the voltage at the level where the power transfer is maximum. The information obtained in the qualitative comparison of behaviors and the accurate information explained were collected, concluding the advantages and disadvantages of each method, with the exception that each technique has its different application.

Note that all the techniques had similar behavior about environmental influences. Even with such a drastic variation in their temperature and irradiation values, the control was able to withstand climate disturbances, where it was concluded that the techniques have excellent reliability before abrupt environmental variations.

\section{AUTHOR'S CONTRIBUTION}

Conceptualization: Miguel Aybar, Yandi Gallego and Lesyani León.

Methodology: Miguel Aybar, Yandi Gallego and Lesyani León. Investigation: Miguel Aybar, Yandi Gallego and Lesyani León. 
Discussion of results: Miguel Aybar, Yandi Gallego and Lesyani León.

Writing - Original Draft: Miguel Aybar, Yandi Gallego and Lesyani León.

Writing - Review and Editing: Miguel Aybar, Yandi Gallego and Lesyani León.

Resources: Yandi Gallego and Lesyani León.

Supervision: Yandi Gallego and Lesyani León.

Approval of the final text: Miguel Aybar, Yandi Gallego and Lesyani León.

\section{ACKNOWLEDGMENTS}

This research was supported by FONDOCYT 2018-20193C1-160 (055-2019 INTEC) in the Dominican Republic.

\section{REFERENCES}

[1] R. Faranda, S. Leva, and V. Maugeri, "MPPT techniques for PV Systems: Energetic and cost comparison," in 2008 IEEE Power and Energy Society General Meeting - Conversion and Delivery of Electrical Energy in the 21st Century, 2008, pp. 1-6, doi: 10.1109/PES.2008.4596156.

[2] M. A. Eltawil and Z. Zhao, "MPPT techniques for photovoltaic applications," Renewable and Sustainable Energy Reviews, vol. 25. Elsevier Ltd, pp. 793-813, 01-Sep-2013, doi: 10.1016/j.rser.2013.05.022.

[3] M. Brito, L. Sampaio, G. Melo, and Canesin CA, "Contribuição ao estudo dos principais algoritmos de extração da máxima potência dos painéis fotovoltaicos," Eletrônica De Potência, vol. 17, no. 3, Aug. 2012, doi: http://dx.doi.org/10.18618/REP.2012.3.592600.

[4] S. B. Kjær, "Evaluation of the 'Hill Climbing' and the 'Incremental Conductance' Maximum Power Point Trackers for Photovoltaic Power Systems," IEEE Trans. Energy Convers., vol. 27, no. 4, pp. 922-929, 2012, doi: 10.1109/TEC.2012.2218816.

[5] S. Oliveira da Silva, L. Campanhol, V. Bacon, and L. Sampaio, "Single-Phase Grid-Connected Photovoltaic System with Active Power Line Conditioning," Eletrônica De Potência, vol. 20, no. 1, pp. 1-11, Nov. 2015, doi: http://dx.doi.org/10.18618/REP.2015.1.008018.

[6] L. Tang, W. Xu, and C. Mu, "Analysis for step-size optimisation on MPPT algorithm for photovoltaic systems," IET Power Electron., vol. 10, no. 13, pp. 16471654, 2017, doi: 10.1049/iet-pel.2016.0981.

[7] S. B. Jeyaprabha and A. I. Selvakumar, "Model-Based MPPT for Shaded and Mismatched Modules of Photovoltaic Farm," IEEE Trans. Sustain. Energy, vol. 8, no. 4, pp. 1763-1771, Oct. 2017, doi: 10.1109/TSTE.2017.2710302.

[8] G. FILHO, R. A. P. FRANCO, and F. H. Vieira, “Algoritmo de Seguimento do Ponto de Máxima Potência para Sistemas Fotovoltaicos considerando Minimização de Erro e Derivada da Potência," Tendencias em Matemática Apl. e Comput., vol. 21, pp. 157-170, Apr. 2020, doi: 10.5540/tema.2020.021.01.00157.

[9] E. N. Chaves, J. H. Reis, E. A. A. Coelho, L. C. G. Freitas, J. B. V Junior, and L. C. Freitas, "Simulated Annealing - MPPT in Partially Shaded PV Systems," IEEE Lat. Am. Trans., vol. 14, no. 1, pp. 235-241, 2016, doi: 10.1109/TLA.2016.7430084.

[10] J. Lopez-Seguel, S. I. Seleme, P. Donoso-Garcia, L. F. Morais, P. Cortizo, and M. S. Mendes, "Comparison of MPPT approaches in autonomous photovoltaic energy supply system using DSP," in 2010 IEEE International Conference on Industrial Technology, 2010, pp. 1149-1154, doi: 10.1109/ICIT.2010.5472594.

[11] Weidong Xiao, W. G. Dunford, and A. Capel, "A novel modeling method for photovoltaic cells," in 2004 IEEE 35th Annual Power Electronics Specialists Conference (IEEE Cat. No.04CH37551), 2004, vol. 3, pp. 1950-1956 Vol.3, doi: 10.1109/PESC.2004.1355416.

[12] D. F. Zaions, A. J. Balbino, C. L. Baratieri, and A. L. Stankiewicz, "Comparative analysis of buck and boost converters applied to different maximum power point tracking techniques for photovoltaic systems," in 2017 Brazilian Power Electronics Conference (COBEP), 2017, pp. 1-6, doi: 10.1109/COBEP.2017.8257383. 